\title{
マグネトロン・スパッタ・ターゲットのエロージョン・レート 分布の数值シミュレーション*
}

小林 司**. 細川 直吉 ${ }^{* *}$. 板垣 克則 $* *$. 内山 智雄 $* *$

（受理1993年12月 2 日，掲載決定1994年 2 月 5 日）

Simulation of Erosion Rate Distribution on a Target used in a

Magnetron Sputtering System

\author{
Tsukasa KOBAYASHI, Naokichi HOSOKAWA, Katsunori ITAGAKI \\ and Tomoo UCHIYAMA
}

(ANELVA Corp., Yotsuya 5-8-1, Fuchu, Tokyo 183)

(Received December 2, 1993, Accepted February 5, 1994)

\section{1.はじめに}

半導体製造用，液晶表示デバイス用のマグネトロン スパッタリング装置は近年ますます大型化する傾向にあ る、そこでは, 経済性の観点からターゲットの利用効率 が常に注目されている。ターゲットのエロージョン形状 は, ターゲットの利用効率や膜厚分布等に直接影響する ため, これを磁界分布等から予測できれば装置設計上非 常に有用と考えられる.

マグネトロン・スパッタリングのターゲット・エロー ジョン分布の本格的シミュレーションは, Wendt $ら^{1)}$ に より初めて報告された。 そこでは, 磁界中の電子の運動 を解析することにより，二次元的なエロージョン分布が 計算されている. Sheridan $ら^{2)}$ は, 磁界中の多数の電子 の運動, イオン化をモンテカルロ法により扱い, 円形カ ソードのエロージョンを解析した。 以後同様な方法によ る解析が種々報告されているが3,4,5)，それらは二次元あ るいは円形カソードに限られていた。最近，吉川ら6)は Sheridan と同様な方法で矩形カソードの三次元シミュ レーションを行なった. モンテカルロ法では, 出発電子

* 平成 5 年11月 29 日第 34 回真空に関する連合講演会で講演

** 日電アネルバ研究開発本部（テ183 東京都府中市四谷 5-8-1）
の分布と最終的に得られるイオンフラックスの分布が矛 盾しないように, 繰り返し計算を行ない収束解を求める 必要がある.この様な計算には多大な計算時間が必要と なり，近年手軽に利用出来るよらになったワークステー ション上での実行が難しい. 今回, Wendt らの方法を 三次元に拡張し，収束解を求めるための繰り返し計算が 不要な方法を検討した。 また，この方法を $15.7 \times 55.88$ $\mathrm{cm}$ サイズの矩形プレーナー型マグネトロンカソードに 適用したところ，実測との良い一致がみられた。

\section{2. モ デル}

マグネトロン放電は, ターゲットに衝突したイオンに より発生した二次電子がシース電界により加速され $\mathrm{Ar}$ 原子に衝突し，これにより発生したArイオンがシース 電界により加速されてターゲットに入射する，といらサ イクルで維持されている. 近似的に, 電界はシース中の みに存在し，バルクプラズマ中では電子は磁界のみによ り拘束されて運動すると考えられる．ターゲット上のあ る微小領域を考えると, この領域から放出された二次電 子はシース電界, 磁界に拘束されて運動し Arをイオン 化することにより, ターゲット上の他の領域のイオンフ ラックスに影響を与えている. Wendt ら ${ }^{1)}$ はこれを数学 的に表現した。位置 $x$ におけるイオンフラックス $j(x)$ 
について次のよらな式が成り立つ。

$$
j\left(x_{\mathrm{k}}\right)=\int K\left(x_{\mathrm{k}}, x_{\mathrm{i}}\right) j\left(x_{\mathrm{i}}\right) d x_{\mathrm{i}}
$$

ここで, $K\left(x_{\mathrm{k}}, x_{\mathrm{i}}\right)$ は $x_{\mathrm{i}}$ から放出された電子が $x_{\mathrm{k}}$ の位置 のイオンフラックスに及ぼす寄与を示す影響関数 (Green function) である.上式は, ある位置の $j(x)$ は ターゲット全域からの電子の寄与の足し合わせであるこ とを表しており, $j(x)$ に対するセルフコンシステント な形式になっている. 上式を数值的に解くことにより, イオンフラックス分布, すなわちエロージョン分布が計 算される.この計算は最終的に固有値問題に㷌着され, $j(x)$ は対応する固有ベクトルとして求まる.

影響関数 $K\left(x_{\mathrm{k}}, x_{\mathrm{i}}\right)$ は電子の運動を解析することによ り計算することが可能である. Wendt らは, 二次元の 問題で, シースが十分薄く電子が磁界のみにより拘束さ れて運動すると仮定すると, $K\left(x_{\mathrm{k}}, x_{\mathrm{i}}\right)$ はベクトルポテ ンシャル $A$ を用いて簡単に表現できることを示した.

一方，三次元の問題でも(1)式は一般的に成り立つ.こ こで $K\left(x_{\mathrm{k}}, x_{\mathrm{i}}\right)$ を計算するには, 個々の電子の電磁界中 での運動を追跡する必要がある. 位置 $x_{\mathrm{k}}$ から出発した 電子の軌道を追跡し, 位置 $x_{\mathrm{i}}$ に拈ける電子密度を求め る.この電子密度と発生するイオンフラックスは比例す ると考えられるので, $K\left(x_{\mathrm{k}}, x_{\mathrm{i}}\right)$ は電子密度の計算から 求められる.

従来行なわ机ていたモンテカルロ法では, 最初にター ゲット上から放出される二次電子の分布を適当に仮定す る.この電子の軌道を追跡しイオン化点を求め, イオン フラックス分布を算出する. しかし，このイオンフラッ クス分布は最初に仮定した二次電子放出分布とコンシス テントでないので，両者の分布が一致するまで Fig. 1(a) のように計算を繰り返す必要がある. 一方 Wendt の方法では, 最初にやはり多数の電子の軌道追跡といら
Monte Carlo method

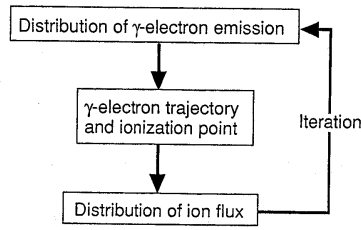

(a)

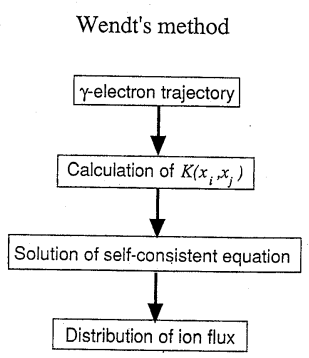

(b)
Fig. 1 Flow charts of the Monte Carlo method (a) and Wendt's method (b) for target erosion simulation in magnetron sputtering.
手間はかかるが, Fig. 1(b) のように(1)式により直接 イオンフラックス分布が求められるため, 繰り返し計算 を行なわずに済むといら利点がある。しかし，今までに 三次元の問題にこの方法を適用した例は報告されておら ず, 本報が初めてである.

\section{3. 計算条件}

前述の Wendt の方法を，実際に15.7 ×55.88 cm サイ ズの矩形マグネトロンカソードに適用した．電子の軌道 を計算するためには，電磁界が既知でなければならな い.ここでは電界はシース中で一定, シース電圧ー400 $\mathrm{V}$, シース厚 $4 \mathrm{~mm}$ とし, バルクプラズマ中では電界ゼ 口と仮定した。 また，三次元の磁界解析は汎用有限要素 法ソフトANSYSにより行なった。これにより得られる 離散的な磁界を内挿することにより，任意の点での磁界 を求めた．解析を行なった $15.7 \times 55.88 \mathrm{~cm}$ サイズの矩形 マグネトロンカソードの形状模式図とターゲット表面上 における磁界分布を Fig. 2 に示す。同図はターゲット 表面に平行な磁界成分 $B_{/ /}$を50ガウス間隔で等高線表示 したもので，右半分のみを示している．端部の $B_{/ /}$は意 罒的に大きくしてある，これは後述するように，基板に 堆積する膜の膜厚分布を均一化するためである.

電子の軌道は10 ps の時間ステップでルンゲ・クッタ 法により計算した．電子がターゲット上から出発すると きの初速度はゼ口とした。Ar原子との衝突は, Sheridan $5^{2)}$ の場合と同様に, 弾性散乱, イオン化散 乱, 励起散乱を考慮し, 更に電子の散乱角度分布も考慮 した，個々の電子の軌道は，電子のエネルギーが Ar の イオン化ェネルギー約 $16 \mathrm{eV}$ 以下になるまで追跡した。 また，簡単のために $\mathrm{Ar}$ との衝突周波数を $1.4 \times 10^{8} \mathrm{~Hz}$ 一定としェネルギー依存性を無視した。これは圧力にし て約1.3 Pa に相当する.

ターゲット・エロージョンの計算は, 対称性を利用し てターゲットの右半分を対象とした．ターゲットの右半 分を約 $5 \times 5 \mathrm{~mm}$ の大きさの格子状領域に分割し, 各領 域から均一に 9 個の電子を放出させ, その軌道を追跡寸 ることにより，他の領域上の電子密度を求めた．この場 合, (1) 式は1375元の非対称行列の固有値問題となり, この解法にはべき乗法を用いた.

\section{4. 計算結果・考察}

以上のようにして計算されたエロージョン分布を Fig. 3 に等高線表示した. また, 部分的に実測と比較し た結果をFig. 4 に示す. 同図には, 矩形ターゲットの 中央部 Y 方向断面（Fig. 2 の A-A A $^{\prime}$ 断面）及び端部 X 方 向断面（Fig. 2 の B-B'断面）におけるエロージョン分布 

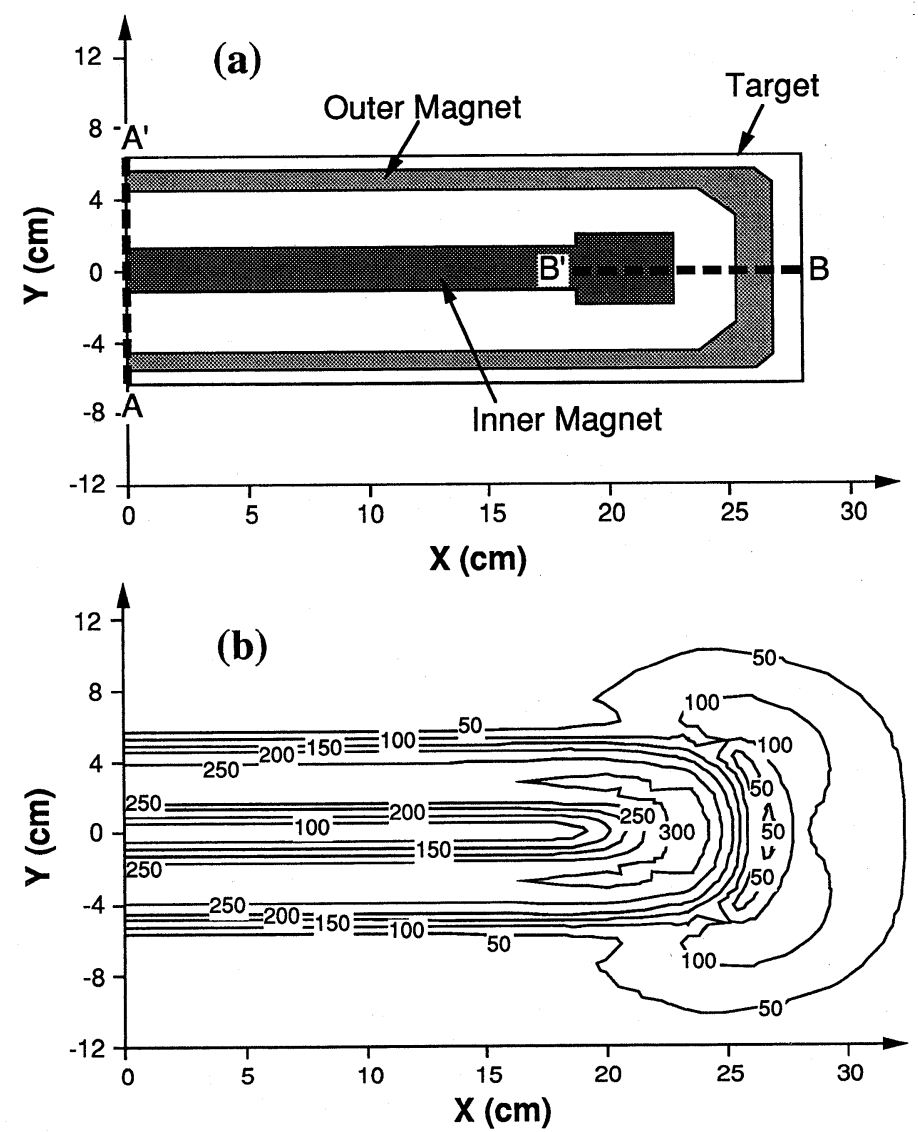

Fig. 2 Configuration of the $15.7 \times 55.88 \mathrm{~cm}$ sized rectangular magnetron cathode (a) and contour lines showing the distribution of magnetic field component parallel to the target surface $\left(B_{/ /}\right)$at the target surface $(b)$. Only right half part is shown. Numbers on the contour lines represent the intensity of $B_{/ /}$in gauss.

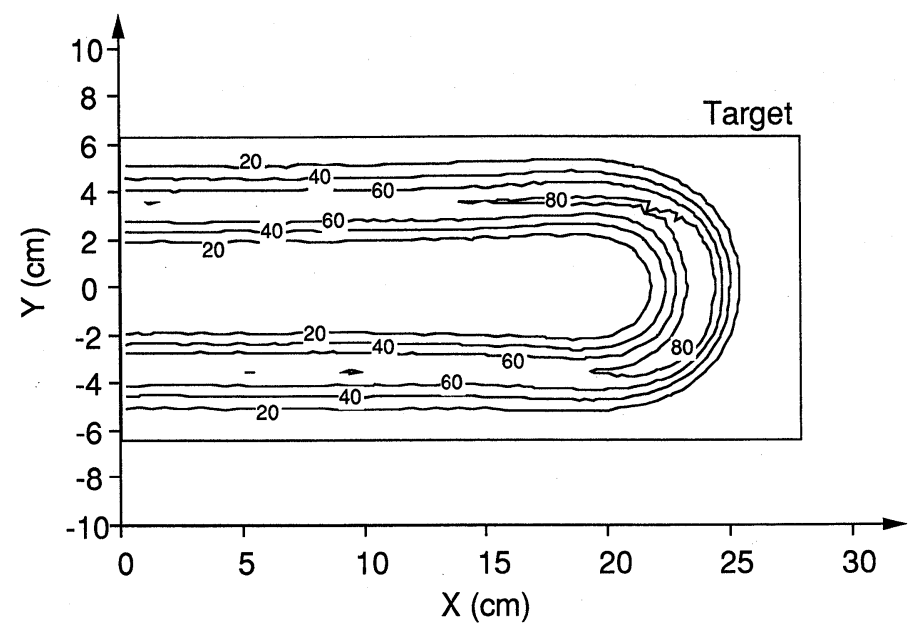

Fig. 3 Contour lines showing the calculated distribution of target erosion in the $15.7 \times 55.88 \mathrm{~cm}$ sized rectangular magnetron cathode. Only right half part is shown. Numbers represent the erosion depth in \% normalized by the maximum. 

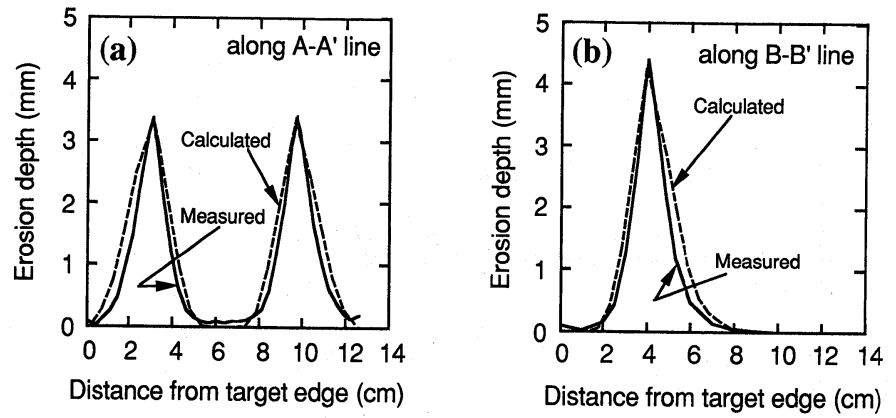

Fig. 4 Cross-sectional profiles of calculated erosion depth (broken lines) and measured erosion depth (solid lines) along A-A' line (a) and B-B' line (b) shown in figure 2 in the $15.7 \times 55.88 \mathrm{~cm}$ sized rectangular magnetron cathode. The calculated curves were adjusted to make the height of the peak coincide the measured one along A- $\mathrm{A}^{\prime}$ line.

を示した．計算値は中央部 Y 方向断面の実測ピーク值

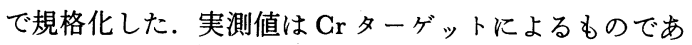
る. 実測值と計算值は良く一致していることがわかる.

ターゲット中央部と端部では, 端部の方がエロージョ ン深さが大きい.これはFig. 2 の磁界分布を反映した ものと考えられる。電界を $\boldsymbol{E}$, 磁界を $\boldsymbol{B}$ と表すと, 電 子は $\boldsymbol{E} \times \boldsymbol{B}$ ドリフト, $\boldsymbol{\nabla} \boldsymbol{B} \times \boldsymbol{B}$ ドリフト, 求心カドリフ ト等により運動して7), 環状のトラックを形成してい る.このドリフト速度は磁界 $B$ が大きい程小さくなる。 そのため, 局所的に $B$ の大きな部分では電子密度が上 昇し，その部分のエロージョン深さが大きくなると考え られる. 実用的な観点からは, この効果により, 基板に 堆積する膜の膜厚分布を均一化することが可能になる.

また， $\boldsymbol{\nabla} B \times \boldsymbol{B}$ ドリフトを考えると，電子が局所的に 磁界の大きな領域に入る場合と出ていく場合で電子のド リフト運動の様子が異なる。これによりェロージョン分 布にも，磁界の大きな領域を境にして（この場合 X 軸 を対称軸として）何らかの非対称性が現われると期待さ れるが，今回の計算では特に目立った非対称性は現われ なかった．実測でもこのような非対称性は汪とんど観測 されていない. Fig. 2 亿示した程度の磁界の不均一性で は， $\boldsymbol{\nabla} B \times \boldsymbol{B}$ ドリフトがェロージョン分布に及注す影響 は小さいと考号れる。

\section{5. まと め}

マグネトロン・スパッタリングのターゲット・エロー ジョンのシミュレーションにおいて. Wendt の方法を 三次元に拡張することにより, 効率の良い計算法を検討 した. この方法では, 従来三次元のモンテカルロ計算で 行なわれていた二次電子放出分布とイオンフラックス分 布とをコンシステントにするための絽り返し計算が不要 となる.この方法を $15.7 \times 55.88 \mathrm{~cm}$ サイズの矩形マグネ トロンカソードに適用したところ，エロージョンの実測 分布と計算結果が良く一致し，このようなシミュレーシ ョンが有効であることが実証された。

\section{〔文献〕}

1) A. E. Wendt, M. A. Lieberman, and H. Meuth, J. Vac. Sci. Technol. A6, (1988) 1827.

2) T. E. Sheridan, M. J. Goeckner, and J. Goree, J. Vac. Sci. Technol. A8, (1990) 30.

3) J. E. Miranda, M. J. Goeckner, J. Goree, and T. E. Sheridan, J. Vac. Sci. Technol. A8, (1990) 1627.

4）井門俊治他, 核融合研究, 68, (1992) 386.

5）稲葉 宏他, 真空, 36, (1993) 539.

6）吉川幸雄他，第10回プラズマプロセシング研究会プ ロシーディンゲス，(1993） 137.

7) J. A. Thornton and A. S. Penfold, in Thin Film Processes, edited by J. L. Vossen and W. Kern (Academic, New York, 1978), p. 75. 